\title{
Diagnosing the Problem of Anti-Politicians: A Review and an Agenda
}

Jack Corbett, Griffith University, jack.corbett@griffith.edu.au

*A slightly amended version of this paper is forthcoming with Political Studies Review

\section{Abstract}

In response to growing popular dissatisfaction with politics and politicians several scholars have sought to explain the cause of this malaise and demonstrate what can be done about it. To tease out the significance of four recent additions to this discussion I review how they diagnose the problem of anti-politicians and what they consider the cure might be. I find that Riddell and Flinders view the problem in terms of an expectations 'gap' while Kane and Patapan, and Medvic cast it as a leadership 'paradox' or an expectations 'trap'. The former two primarily sees greater citizen participation, generated via institutional reform or revived civic values, as the solution, whereas the latter two question whether the problem can or should be solved at all. I conclude that while these books provide important insights, by and large they neglect to take serious or systematic account of the views, experiences and reflections of political leaders themselves. To take this research agenda forward I argue that this omission warrants further attention.

Keywords: anti-politicians, demonization of politicians, anti-politics, depoliticization, democratic disillusionment, political leadership 


\section{Diagnosing the Problem of Anti-Politicians: A Review and an Agenda}

Popular faith in politicians has, according to newspaper columnists, talkback radio hosts, surveys and opinion polls, reached all-time lows. It often seems as though we cannot go through a single day without some new scandal or misdemeanour reaffirming the commonly held view that all politicians are self-interested, hypocritical and dishonest. Politicians, we are told, are parasites who squander public funds through mismanagement, reckless waste and extravagant salaries and perks. Rather than rational deliberation, moderation and consensus on behalf of the people they represent, the halls of parliament more commonly depicted as a 'circus' where members attempt to score cheap partisan points for headline writers without due concern for long-term national interests. While we continue to hold out the possibility that a truly virtuous and honest leader will rise above this malaise, sadly, according to this prevailing view, such individuals are rapidly absorbed by the imperatives of the 'system' and the 'rules of the game'. Combined, the impression created by this litany of deeply held beliefs is that the people who occupy authority roles have become increasingly demonised for undertaking their job.

But who is to blame for this set of circumstances and what can be done about it? Fifty years since Bernard Crick (2000 [1962]) first took up his cudgel on behalf of the messy, unpredictable and sometimes grimy process that he called 'mere politics', scholars are increasingly returning to similar questions. Much of this work is concerned with 'antipolitics' broadly defined but here I focus specifically on popular disaffection directed at politicians (i.e. 'anti-politicians'). Four of the most recent additions to this genre are Peter Riddell's (2011) In Defence of Politicians; John Kane and Haig Patapan's (2012) The Democratic Leader; Matthew Flinders In Defence of Politics (2012); and Stephen Medvic’s 
(2013) In Defense of Politicians. ${ }^{1}$ In this article I review these contributions to consider how they diagnose the problem of anti-politicians and outline what the possible cures might be. Where relevant I also draw on related works on anti-politics to situate their contribution both in relation to each other and this wider debate. While interested in broadly the same phenomenon - perhaps best evidenced by two sharing the same title - these authors see both the problem and the solution differently. I conclude that while each book has much to offer our understanding of why democracies do not like their politicians, in none of these accounts do we hear much from politicians themselves. To form a holistic picture of this phenomenon, and thus move this debate forward, I conclude that this is the next gap that needs to be filled.

\section{Diagnosing Anti-Politicians}

Politicians have never been popular, Riddell (2011) reminds us, but the depth of disenchantment today is so serious that it casts doubt on the legitimacy of representative politics as, at least in Britain, it has become a pervasive feature of political life. Riddell's (2011) In Defence of Politicians is premised on the assumption that if we believe in politics defined as the peaceful reconciliation of difference - then we also have to defend politicians, as the class of people are intrinsic to the activity (cf. Wright 2013). This defence, however, must often be undertaken 'in spite of themselves' as for Riddell (2011), the excesses and weakness of politicians is a major contributor to the problem. Some of these failings are endemic - the usual clash of personalities and interests - but others are new and it is these new challenges and the intensification of popular criticism that he is primarily concerned with:

\footnotetext{
${ }^{1}$ I acknowledge that of the four Flinders book sits slightly uncomfortably in this group as unlike the other three it does not explicitly focus on politicians, but, given that it has strong views on the topic, I have included it to balance the discussion.
} 
... such a world-weary shrug will no longer do. The challenges ... are not only serious in themselves, albeit often exaggerated, but they are cumulatively, worse than in the past. Crucially, the current low standing of politicians means that representative democracy does not - and cannot - work as it should. Not only is government made harder, but the anti-politician mood has encouraged the search for alternative approaches which threaten to undermine representative democracy (Riddell, 2011, p. 140-141)

Unlike the other works considered here, Riddell (2011) does not diagnose one problem or cause of prevailing anti-politician sentiment, but rather he identifies several, including media driven populism, excessive partisanship, unrealistic voter expectations, institutional decline (both parliamentary and constitutional), and even the academy, whose methods he argues are so out of touch with the way politics is actually practiced that most scholarship fails to provide genuine insights about how the political process actually works.

To read many political science journals is to enter an enclosed and often narcissistic world of academics writing for each other ... it is self-referential, as well as selfreverential, and often unreadable to anyone but a narrow group of specialists (Riddell, 2011, p. 10).

In contrast to the scholarship he critiques, Riddell's (2011) account is grounded in his extensive experience as a journalist, which can help us understand that breadth of ailments he prescribes. It is difficult, however, to tie all of the threads together into a theoretical account as he comes at the problem from multiple angles. In part this is the strength of his insight - it largely eschews theory but is instead embedded in observed practices (he describes his book on page 6 as a 'polemic laced with autobiography') - but the downside is that his argument lacks the focus that theory might provide. In setting up his argument he does, as I will discuss 
further below, acknowledge the inherent contradictions that sit at the heart of democratic government between the need for politicians to be both apart from the mass and also dependent on their continued support. However, this is not the main focus of his account.

A more theoretically orientated version of Riddell's (2011) argument can be found in the anti-politics literature and Pippa Norris' (2011) book Democratic Deficit: Critical Citizens Revisited. Unlike Riddell (2011), Norris (2011) is not specifically concerned with the demonisation of politicians but we can draw some parallels in her diagnosis of ever-growing public disenchantment with politics and governemnt, and Riddell's (2011) account. For Norris (2011), the problem arises from the difference between the demands critical citizens (highly educated, affluent, post-material and self-expression values) have of their democracy, fanned in part by saturated media coverage (which frames politics in a consistently negative light), and the performance (process, outcomes and structure of power sharing) of public institutions:

The most plausible potential explanations for the democratic deficit suggest that this phenomenon arises from some combination of growing public expectations, negative news, and/or failing government performance (Norris, 2011, p. 5).

Combined, Riddell (2011) and Norris' (2011) diagnosis depicts an expectations 'gap' between what people want and what the system of political institutions we have can provide.

Flinders' (2012a) book Defending Politics would not necessarily disagree with this depiction but his diagnosis drills in on the decadent expectations that citizens have of their government as the main problem; there is a causal story here that is downplayed in Riddell's (2011) account. Of the four books, Flinders' (2012a) most explicitly links his work to Crick (he published it on the $50^{\text {th }}$ anniversary of Crick's book). Like Crick (2000 [1962]) and Riddell (2011), Flinders' (2012a) coverage of the problem - defined as a 'bad faith model of politics' 
- is broad and includes chapters that defend politics against the 'market', 'denial', 'crisis' and the 'media'. At the heart of his diagnosis is a concern with the danger of growing 'democratic decadents’ or public apathy amongst (young) citizens who take liberal freedoms for granted (Flinders, 2012a, p. 160). Indeed, unlike Riddell (2011), who unequivocally argues that there has never been a 'golden-age' where politicians generated the respect that they deserve, Flinders' (2012a) book is infused with a strong sense of nostalgia for the post-war period, when, he argues, people appreciated community and democracy, and understood the dangers of totalitarianism and nationalism, as opposed to the prevailing values of the internet generation:

... the contemporary climate of anti-politics is arguably rooted in a generation that has become complacent and parochial, and in doing so have forgotten the alternatives to democratic politics, by which I mean the human cost, the pain, and the suffering that occurs when democratic politics truly fails (Flinders, 2012a, p. ix).

Consequently, where Riddell (2011) sees unrealistic citizen expectations as only one contributor to the 'gap' between what we want and what we get from our democracy, Flinders concentrates much of his censure at decadent citizens; his is a demand side account of why the 'gap' exists.

From this 'demand side' perspective, the problem is 'the people' who are generally apathetic towards their civic duties, which leads to corrosive cynicism. In this view, media driven populism, excessive partisanship and institutional decline are all consequences of the broader problem that, put crudely, people are not prepared to participate in their democracy to the extent that is required for it to function appropriately. ${ }^{2}$ In this sense, Flinders (2012a) sees the

\footnotetext{
2 Flinders' (2012a) account bears some resemblance to Hibbing and Theiss-Morse's (2002) depiction of 'stealth democracy' where citizens simply do not want to be involved in what they see as an inherently compromised and dishonest enterprise, and are increasingly suspicious of those who do.
} 
problem in the opposite terms to someone like John Keane (2009) whose The Life and Death of Democracy extols the capacity of new media in particular to enable citizens to hold their governments to account. Rather than being an asset, for Flinders (2012a, p. 43) these developments are part of the problem as they encourage cynicism about the motives of politicians. Instead of narrowing the expectations 'gap', perversely these technologies serve to widen it. Similarly, Flinders' (2012a) view diverges from some of the earlier works in this genre, including Gerry Stoker’s (2006) Why Politics Matters and Colin Hay’s (2007) Why We Hate Politics, which both see the expectations 'gap’ as primarily 'supply side’ driven; that is, declining participation is not a function of 'decadent democrats' but rather of the various institutional barriers, namely the professionalisation of the political process, that precludes their engagement (Stoker and Hay 2009). From this perspective, professionalization, a trend that Riddell has commented on elsewhere (see Riddell 1993), results in the institutional features of our political system (including party bureaucracies) conspiring, consciously or unconsciously, to insulate politicians from the people they are supposed to represent. In both 'supply' and 'demand-side' accounts of the expectations 'gap', authentic representation is the goal but unlike Riddell (2011), who includes them both, Flinders and these other works privilege one as having more causal significance over the other.

Kane and Patapan's (2012) The Democratic Leader and Medvic's (2013) In Defense of Politicians diagnoses the problem of anti-politicians in a fundamentally different light. That is not to say that these two books are the same - Kane and Patapan's (2012) discussion is primarily theoretical whereas Medvic (2013) brings a range of survey evidence to bear on the question at hand and is explicitly focused on the United States - but both end up with a very similar diagnosis to the problem of anti-politicians that differs from that provided by either Riddell (2011) or Flinders (2012a). Rather than an expectations 'gap', driven by either the demand or supply side (or in Riddell's case, a combination of both), they emphasise an 
expectations ‘trap’ (Medvic 2013) or a ‘democratic leadership paradox’ (Kane and Patapan 2012); an irreconcilable tension that sits at the heart of the way we think about democratic government that drives much of the current disaffection directed at politicians.

For Kane and Patapan (2012) the democratic principle of popular sovereignty, where all people are equal, is at the heart of the problem we have with our politicians.

The dynamic tension between the limited authority leaders are actually granted and the extensive authority they are expected to wield makes democratic leadership distinctively what it is: both the strongest and weakest form of leadership (Kane and Patapan, 2012, p. 1).

Their book does not attempt to either defend elitism or call for enhanced participation; most people want both. And this, more than anything, is the fundamental cause of popular disaffection. For Kane and Patapan (2012), the ground on which politicians stand is perpetually insecure as they embody a broader societal debate about how much authority leaders should have and how that authority should be exercised. This is what makes democracy distinct. It needs leadership but at the same time by constantly confirming the sovereignty of the people it actively works to undermine any authority that leaders might have. This is both its greatest strength - its popular legitimacy gives politicians the right to enact change - but also its greatest weakness - it never quite grants leaders the control to achieve it. In contrast to Riddell (2011) and Flinders (2012a), Kane and Patapan (2012) argue that we cannot and should not seek to solve the problem of anti-politicians, as it is the very thing that makes democracy what it is. So, rather than closing the 'gap', the key is actually to maintain the tension, as without it democracy is no longer democratic.

Medvic’s (2013) argument is similar but different (partly this is because Medvic (2013) sees much of the problem in terms of the constitutional checks and balances contained in the 
American constitution whereas Kane and Patapan (2012) write for a much broader audience). Politicians, for Medvic (2013), are the victims of an 'expectations trap’, or rather three 'traps' that, when combined, underpin our collective dissatisfaction. The first, echoing Kane and Patapan (2012), is the 'Leader-and-Follower Trap'. We want politicians to be leaders and exert control - we perpetually lament the lack of leadership - whilst also demanding they take account of our preferences when making decisions; they need to lead and follow simultaneously. The second, is 'The Principled-and-Pragmatic Trap' where we want politicians to hold firm to their beliefs - we decry opportunism - and yet at the same time compromise to solve problems. The third, is 'The Ordinary-and-Exceptional Trap' where we want to be represented by people like us, so they can understand us, but also better than us, so they can rule over us legitimately.

Combined, the problem for Medvic (2013) isn't simply that each of us wants different things from our politicians, but that we actually share contradictory expectations of who politicians should be and how they should behave. Like Kane and Patapan (2012), Medvic (2012) argues that no politician can escape these 'traps', as they are inherent to the purpose of the job. The two books differ slightly in that Kane and Patapan (2012) see one 'paradox' as paramount whereas Medvic (2013) explicitly disaggregates his account into three (although, all three can also be found in Kane and Patapan’s (2012) book, even if the ‘Leader-and Follower Trap’ takes precedence). Nevertheless, rather than solving the problem or closing the 'gap', both conclude that all we can do is recognise the limitations that politicians labour under and be more sympathetic to the paradoxical job that we ask them to undertake.

\section{Curing Anti-Politicians}

Combined, Kane and Patapan and Medvic point us away from what is new about contemporary disaffection directed at politicians (Riddell, Flinders) and instead ask us to 
focus on what is constant. Both books acknowledge that demonization is detrimental to the practice of sound government - although, of the two, Medvic (2013) is more insistent on this point - and neither entirely dismiss reform efforts - contained within Medvic’s (2013, p. 133139) analysis is a critique of the way the political system in the United States operates that, at times, echoes Flinders (2012a) - but this alone will not solve the problem, and so both eschew a cure or solution. Implicitly, however, both provide one all the same. Rather than attempting to 'cure' the antipolitician problem - we are going to have to live with it to some degree - they argue we should aim to temper it. Yet, having prescribed moderation, neither outlines at any great length how this might be achieved; the assumption is that once we realise the nature of the 'trap' we will automatically be more sanguine about the failings of democratic leaders. However, while theoretically elegant this conclusion is inevitably disappointing to those with more normative aspirations as, aside from offering solace that it was ever thus, it provides no clear map for how the current trend or prevailing 'sickness unto politics’ (Flinders 2012a) might be altered. In contrast, both Riddell (2011) and Flinders (2012a) spend much more time on these points.

Riddell (2011, p. 154-181) puts forward 12 answers to the 'what can be done?' question that include: measures to improve the conduct of politicians by cleaning up their financial affairs (i.e. the UK expenses scandal); increase their effectiveness and connection with the public by instituting changes to parliamentary procedures and enhancing constituent access; the reorganisation of political parties and candidate selection to allow for greater citizen participation; and media reform (journalists need to better distinguish between errant individuals and politicians as an indispensable group). Ultimately, for Riddell (2011), positive actions of this type by politicians in particular would make them easier to defend. And, as a result, would close the expectations 'gap' that he see as being at the heart of the current malaise. 
The solution for Flinders (2012a) is put more succinctly: citizens should be more involved in political processes. Again, this does not contradict Riddell (2011) but the emphasis is different. Rather than requiring political elites to concede power, for Flinders (2012a) the free-riding public is not keeping up their end of the democratic bargain. If they did, and thus took the opportunity that is available to them and became more involved, their awareness of the practical limitations that constrain what politicians and democratic politics can and does achieve would be raised, and they would better appreciate the value of what they have. The point then is not that politicians should be more honourable, but rather that they are more honourable - our mistrust is consistent with other forms of moral panic (Jones, 2008; Flinders, 2012b; Wood and Flinders, 2012) - we just fail to appreciate it. ${ }^{3}$ This apathy, he argues, is cancerous to a democratic system that needs active and politically conscious citizens to generate the requisite trust and generalised reciprocity.

There are other ways that we can conceptualise the problem of anti-politicians than outlined in the main four books reviewed here. Certainly, despite the differences, all share a conventional definition of politics as having something to do with turning conflict into consensus. Others, like Henrik Bang (2005, 2011), would disagree. Bang's (2005, 2011) contribution has been reviewed elsewhere (Marsh, 2011) so I will not provide an eleborate discussion here but, put simply, he rejects this definition of politics as fundamentally inputfocused (turning conflict into consensus) and instead also calls for a focus on the 'output' or 'policy-politics' side of the equation. Disaffection with politicians, from this perspective, emerges from the blurring of the boundary between 'inputs' and 'outputs'. For Bang (2005, 2011) the expectations 'gap' or 'trap' exists because our definition of politics only allows us to focus on one-side (the 'input-side') of the problem. If we had a more holistic definition of

\footnotetext{
3 Flinders' (2012a) echoes Robert Putnam (2000) here who famously argued that a variety of factors have fundamentally altered the nature of civic association since the 1960s, ultimately begetting poor community life.
} 
politics then we would be able to understand the more facilitative and empowering aspects of the way government's function. Having said that, within the conventional parameters of politics as a means of turning conflict into meaningful consensus, all four books provide important contributions in their own right.

\section{Bringing the Politician Back In?}

Despite the important theoretical, empirical and practical contribution that these works offer, we hear very little from politicians themselves in this debate. This is, I believe, a significant oversight. Consequently, and here I agree with Hay (2007, p. 162) and Medvic (2013, p. 20), given the pervasiveness of anti-politician sentiment, we need to know more about the people who run for public office, their stories and experiences. Asking after politicians' views on political life is not new, but, by and large, the literature on what it is like to be a politician (for review see [omitted]) is rarely linked with contemporary debates about anti-politics and anti-politicians. The same can be said for the genre of political biography and autobiography which contains numerous insights about the experience of holding public office that are of relevance to this discussion (Rhodes, 2012; Arklay et al., 2006).

If we follow Riddell (2011) and Flinders (2012) and see the ‘problem' as a 'gap', then the views and experiences of politicians are important because they are caught in the middle of it - they are at the frontline - and thus have a unique insight into the competing demands placed upon them by critical citizens, saturated media coverage and the falling performance of public institutions. Democracy ensures that politicians have a vested interest in engaging citizens and so, from either a 'demand' or 'supply' side perspective, we have much to learn about their efforts to involve them in the democratic process, including when and why their efforts succeed or fail. In doing so we gain a more holistic picture of where the 'gap' is widest and the problem deepest. For example, a politicians' constituent office provides a 
crucial link between citizens and public institutions, and yet we know very little about the types of work these offices do, the demands citizens place upon them, or the resources politicians are given to meet their needs. If the 'gap' places democracy under stress then sites like these are the key to understanding, at an everyday level, what these pressures are and how they might be relieved.

Likewise, if we follow Kane and Patapan (2012) and Medvic (2013) and see the problem as an expectations 'trap' then a similar emphasis on the everyday lives of politicians can help us understand how they go about reconciling competing expectations and interests. In learning more about what it is like to be a politician, we might regain a degree of respect for the people who hold public office and the perpetually precarious environment in which they operate. Medvic (2013, p. 89-120) already takes us part of the way with his discussion of their 'inner lives', but there is further to go. From this perspective, this 'insider' view will not solve the problem of anti-politicians but by walking a mile in their shoes we might develop a more sympathetic (and therefore more moderate) view of the job they do.

Finally, as alluded to in my brief discussion of Bang's (2005; 2011) work, the views of politicians have the potential to open up deeper theoretical questions about authority roles and the nature and purpose of political action. Much of the work canvassed here sees politics as an effort to turn conflict into consensus. In contrast, a renewed focus on the people who do the job can provide a more human portrayal of political life that allows for a more positive and constructive view of political power. Much anti-politician sentiment assumes that public office holders are self-interested and power hungry; but presumably politicians believe they can and do make a constructive difference in the lives of the citizens they represent. By asking what motivates people to run for office, what it is like for those who get elected, and what influences their decisions, we gain a fresh insight into the way authority roles function 
in modern democratic government, and a better understanding of how the difference politicians make in the lives of citizens is communicated to voters.

Studying politicians is not without its limitations. For one, political elites are commonly seen as remote and inaccessible. And yet, as scholars who have done this type of work will attest, while access remains precarious it can be successfully negotiated. In the 1970s, senior civil servants were believed to be unreachable and yet Heclo and Wildavsky (1974) gained access and produced a classic study of how government works (for review see Weller 2014). Their example has inspired others whose analysis of executive politics in particular has drawn heavily on interviews (e.g. Searing 1994; Reeher 2006; Tiernan and Weller 2010; Rhodes 2011; [omitted]), and whose work serves as a template for future research.

The other commonly cited limitation is that even if we could access these types of reflections, how would we know if and when we are being told the 'truth'? On one hand, this concern is part of the puzzle (the assumption is that politicians are better at manufacturing 'spin' than us mere mortals). But on the other, it is no doubt correct to assume that politicians would prefer to cast themselves in a positive light if asked about their job. There are a number of ways to respond to these concerns and there is much to be learnt from other disciplines, like anthropology for example. These questions also have deep ontological and epistemological roots that I cannot canvass here. But, for the purposes of this discussion, let me provide two brief answers.

First, and perhaps most obviously, just because a politician's account only tells one side of the story does not mean the insight has no value. Perversely, given the prevailing popular critique, a counter-narrative represents an important contribution. In their own way, each of the books discussed here makes that case already. But, including the views of politicians about their job and how they see it as contributing to popular disaffection would allow us to 
hear it from the source. Second, there are standard methodological techniques that can be employed to validate the views of interviewees. Heclo and Wildavsky (1974) did not try to resolve specific cases but instead sought to understand general norms and patterns: they did not ask 'how have you been done over' but 'how do people normally do each other over'. Their point was that the nature of the question reduces the propensity for self-serving defensiveness and thus allows for more general insights. Moreover, scholars interested in how politics is practised can always contrast the views of interviewees with their own observations. To do that, they have to 'be there' themselves but, as Rhodes' (2011) has most recently shown, the intellectual payoffs of such work can be substantial.

Ultimately, on its own, the reflections of politicians about a topic like this are not the only insight we would want to rely on. However, given that the views of citizens have been extensively surveyed, and theoretical work of the type discussed here is becoming increasingly thorough, the time has come to also ask politicians about their job and the ways it might contribute to the perpetuation or escalation of anti-politician sentiment. Their reflections can only provide one-side of an inherently complex story, but, given they are the main characters, it seems counter-productive that we should continue to omit them entirely from our rendering of it. 


\section{Bibliography}

Arklay, T., Nethercote, J. and Wanna, J. (eds)., 2006. Australian Political Lives, Canberra: ANU E Press.

Bang, H., 2005 'Among everyday makers and expert citizens', in J. Newman (ed) Remaking governance: peoples, politics and the public sphere. Great Britain: The Polity Press, pp. 159-178.

Bang, H., 2011. 'The politics of threats: late-modern politics in the shadow of neoliberalism', Critical policy studies, 5(4), 434-448.

Crick, B., 2000 [1962]. In Defence of Politics, Great Britain: Continuum.

Flinders, M., 2012a. Defending Politics: Why Democracy Matters in the Twenty-First Century, Oxford and New York: Oxford University Press.

Flinders, M., 2012b. 'The demonisation of politicians: moral panics, folk devils and MPs' expenses', Contemporary Politics, 18(1), 1-17.

Hay, C., 2007. Why We Hate Politics, Cambridge: Polity Press.

Hay, C. and Stoker, G., 2009. 'Revitalising Politics: Have We lost the Plot?', Representation, 45(3), 225-236.

Heclo, H. and A. Wildavsky., 1974. The private government of public money: Community and policy inside British politics, Macmillan London.

Hibbing, J. R. and Theiss-Morse, E., 2002. Stealth democracy: Americans' beliefs about how government should work, Cambridge University Press.

Jones, K., 2008. 'Professional Politicians as the Subjects of Moral Panic', Australian Journal of Political Science, 43(2), 243-258.

Kane, J. and Patapan, H., 2012. The Democratic Leader: How Democracy Defines, Empowers, \& Limits its Leaders, Oxford: Oxford University Press. 
Marsh, D., 2011. 'Late modernity and the changing nature of politics: two cheers for Henrik Bang', Critical policy studies, 5(1), 73-89.

Medvic, S.K., 2013. In Defense of Politicians: The Expectations Trap and Its Threat to Democracy, New York and London, Routledge.

Norris, P., 2011., Democratic Deficit: Critical Citizens Revisited, Cambridge: Cambridge University Press.

Putnam, R. D., 2000., Bowling alone: the collapse and revival of American community, New York, Simon \& Schuster.

Reeher, G., 2006. First Person Political. New York and London, New York University Press.

Rhodes, R. A. W., 2011. Everyday Life in British Government. Oxford and New York, Oxford University Press.

Rhodes, R. A. W., 2012. 'Theory, Method and British Political Life History', Political Studies Review, 10(2), 161-176.

Riddell, P., 1993. Honest Opportunism: The rise of the career politician. London: Hamish Hamilton.

Riddell, P., 2011. In defence of politicians:(in spite of themselves), London, Biteback.

Searing, D., 1994. Westminster's World. Cambridge, Massachusetts and London, England, Harvard University Press.

Stoker, G., 2006. Why Politics Matters: Making Democracy Work, Houndmills [England]; New York: Palgrave Macmillan.

Tiernan, A. and P. Weller., 2010. Learning to Be a Minister: Heroic Expectations, Practical Realities. Melbourne, Melbourne University Press.

Weller, P. forthcoming 2014., 'Anticipating interpretivism: Heclo and Wildavsky as pioneers?’ The Australian Journal of Public Administration.

Wright, T., 2013. "What is it about politicians?" The Political Quarterly 84(4): 448-453. 
Wood, M., \& Flinders, M. 2012. 'From Folk Devils to Folk Heroes: Rethinking the Theory of Moral Panics’. Moral Panic Studies Working Paper Series, 2012/2. 